\title{
Technical and economic evaluation of the utilization of solar energy at South Africa's SANAE IV base in Antarctica
}

Authors

Jürgen R. Olivier $^{\mathrm{H}}$, Thomas M. Harms ${ }^{*}$, Daniël J. Esterhuyse ${ }^{\S}$

\section{Affiliations}

${ }^{*}$ T.M. Harms is affiliated to: Department of Mechanical Engineering; University of Stellenbosch; Private Bag X1; Matieland 7602; South Africa

${ }^{\mathrm{H}}$ J.R. Olivier is affiliated to: Department of Mechanical Engineering; University of Stellenbosch; Private Bag X1; Matieland 7602; South Africa

${ }^{\S}$ D.J. Esterhuyse is affiliated to: South African Weather Service; Private Bag X097; Pretoria 0001; South Africa

\footnotetext{
* T.M. Harms is the corresponding author during review. Fax: (+27 21) 808-4958; Email: tmh@ sun.ac.za
} 


\section{Abstract}

The technical and economic feasibility of utilizing solar energy at South Africa's SANAE IV station in Antarctica was evaluated in order to estimate potential financial and external savings, and to alleviate the programme's dependence on the special blend of diesel shipped annually from Cape Town. The average global-horisontal and tilted insolation rates at the base were studied, energy consumption data of the station was investigated, technical performance characteristics of devices for harnessing solar energy were assessed and an economic analysis was completed. It was shown that at SANAE IV flat-plate solar thermal collectors could potentially be used in conjunction with the snow smelter (a device that meets the station's fresh water demand) and that photovoltaic modules could feasibly be used to reduce the station's electrical demand. Flat-plate solar thermal collectors could collect solar energy at an average of $3.13 \mathrm{R} / \mathrm{kWh}$ (viz. $0.49 \mathrm{US} \$ / \mathrm{kWh}$ ) from a suggested $143 \mathrm{~m}^{2}$ array, while comparatively a $40 \mathrm{kWp}$ photovoltaic system would be less economically sound and only able to pay back costs in the long term, generating electricity at an estimated $3.20 \mathrm{R} / \mathrm{kWh}$ (annual electrical consumption at SANAE IV amounts to more than $1062 \mathrm{MWh}$ ). The total diesel savings of the solar thermal and photovoltaic systems were estimated at approximately 12245 liters and 9958 liters respectively, which represent savings in externalities of R 67338 and R 55879 each.

\section{Keywords}

Solar energy; Antarctica; Feasibility study; SANAE IV; Technical Analysis; Economic analysis

\section{Main Text}

\section{INTRODUCTION}

A significant cost component of operating South Africa's Antarctic SANAE IV station currently depends on the volatile price of oil. Each year the station's electrical consumption is generated 
from roughly 297872 liters of Special Antarctic Blend (SAB) diesel that can only be transported from Cape Town with considerable logistical and financial effort, resulting in an estimated pointof-use cost triple that of the purchase price. Growing concern about future oil security, a continued effort to improve the performance of the station with reduced financial commitment, but above all the Antarctic Treaty's mandate to protect the unspoiled environment lends itself to an investigation of utilizing solar energy at South Africa's SANAE IV station $\left(70^{\circ} 40^{\prime}\right.$ South and $2^{\circ} 49^{\prime}$ West).

Meanwhile progress in the utilization of renewable energy resources on Antarctica has taken place. Fourteen stations are at present utilizing renewable energy on the continent, mainly wind, of which six bases employ solar energy systems (COMNAP, 2005). Continued research pertaining to the Australian Antarctic Division (AAD, 2005) has also shown that solar thermal devices can perform satisfactorily in these conditions, as is currently the case at the Australian Davis station, while large photovoltaic arrays have been installed at the American McMurdo and Japanese Syowa stations ( $323 \mathrm{~m}^{2}$ and $236 \mathrm{~m}^{2}$ respectively).

This paper presents results from the study of factors relevant to the utilization of solar energy at SANAE IV. Global horisontal and tilted insolation rates at SANAE IV are calculated, the station's energy systems and annual average electrical consumption is analyzed, performance estimates of photovoltaic and flat plate solar thermal devices are given, and financial and external savings are established in the economic evaluation.

\section{ANALYSIS PROCEDURE}

The investigation was undertaken by considering four criteria in turn, namely; availability, demand, devices and costs. That is; the availability of the solar energy resource at SANAE IV, 
total energy demand at the station, potential solutions to harnessing the solar energy in the given conditions, and the complete system lifecycle costs.

The results from each of these four criteria were used to establish and compare potential savings that could be generated for the programme, and the details of this investigation have been discussed here under the sections of; solar radiation analysis, station energy demand analysis, device characteristics and energy production, and economic analysis respectively.

Costs have been expressed in Rand values (South African currency) of December 2005, but can be converted to the equivalent American Dollar amounts of that time by multiplying with 0.158 (US\$/ZAR). Furthermore, the economic analysis has been presented in real terms (that is as December 2005 Rands).

\section{COMPLETE DATA CAPTURE}

During a field trip to SANAE IV (in the summer season of 2004/2005) the following data was acquired:

- Eighteen consecutive days of January radiation measurements obtained using two Kipp \& Zonen CM5, and a Kipp \& Zonen SP-Light pyranometer (which included measurements of global horisontal, horisontal diffuse global tilted radiation),

- Corresponding temperature measurements of the pyranometers, photovoltaic module and ambient conditions using T and K-Type thermocouples,

- Energy production data from a 5 Watt Liselo-Solar photovoltaic module,

- Historical data of electricity generation and the corresponding diesel consumption during 2000, 2001, 2002, 2003 and 2004, 
- An investigation of the station's fresh water consumption and the production rates of the snow smelter (a device used to melt snow in order to create fresh water for the station), and

- General information regarding all the power systems and power distribution was collected and compiled into an energy audit of the station.

\section{SOLAR RADIATION ANALYSIS}

A critical component of the feasibility study was an assessment of the solar radiation expected throughout the year at SANAE IV. Significantly, however, there was no historical data available for analysis from the station, except for measurements obtained during a field trip in January 2005 (detailed in the previous section and subsequently referred to in context). Not able to use long term averages to estimate insolation rates a number of other resources were consulted. These included the Langley Research Center of the National Aeronautic and Space Agency (NASA) that has compiled a Surface Meteorology and Solar Energy Dataset (SSE dataset) from; satellite data, ground-based comparisons and various correlations (SSE, 2005). The dataset makes estimates of radiation values available for every location on Earth. Data recorded at the German Neumeyer Station $\left(70^{\circ} 39 ' \mathrm{~S}, 8^{\circ} 15^{\prime} \mathrm{W}\right)$, located approximately $300 \mathrm{~km}$ from SANAE IV and the South African station's closest neighbor, was also utilized (Neumeyer, 2005). Neumeyer is a contributor to the Baseline Surface Radiation Network. Cloud cover data was consulted for comparative purposes, and methodologies presented by Duffie and Beckman (Duffie et al., 1991) were used to approximate insolation on tilted surfaces from values of global horisontal radiation.

This investigation into available radiation established a number of important conditions. Firstly, as can be seen in Figure 1, during January the values provided by the SSE dataset under-predict global horisontal levels of radiation at Neumeyer. It is also evident that the suggested amount of 
diffuse radiation, calculated using the correlation devised by Erbs et al. (Erbs et al., 1982), is underestimated.

Secondly, it was established that the measurements of solar radiation taken at SANAE IV and shown in Figure 2 were obtained during a relatively cloudy period. The clearness index of the data was calculated as $51.2 \%$, which is less than the long-term January average of Neumeyer (viz. $63.7 \%$ ). Yet, Neumeyer is known to have on average greater amounts of cloud-cover than SANAE IV (Neumeyer, 2005; SAWS, 2005). In this instance the SSE dataset values show an acceptable correlation with the measured values of radiation, however. The dataset could therefore at best be used as a conservative approximation of the average global horisontal solar radiation at SANAE IV.

Upper limits of expected radiation at SANAE IV were established by investigating clear-sky conditions. It was found that the clear-sky models of the American Society of Heating, Refrigeration and Air-Conditioning Engineers (ASHRAE), as well as Hottel (Hottel, 1976), both significantly under predicted measured values of radiation, and that the expected value of clearsky January horisontal radiation is $9.1 \mathrm{kWh} / \mathrm{m}^{2}$.

Considering that the levels of solar radiation at Neumeyer are higher than the SSE dataset values for SANAE IV, it is evident that the Neumeyer measurements offer a more accurate estimate of the actual conditions at the South African station than those suggested by the dataset. As has been stated already cloud cover levels at Neumeyer are greater than those at SANAE IV (which is true throughout the year), and as such radiation measurements from Neumeyer still offer a conservative estimate of the conditions at SANAE IV. These estimated and slightly adjusted values of global horisontal radiation at SANAE IV are shown in Figure 3 alongside estimates of 
radiation at the French Dumont d'Urville (Steel, 1993), Swedish WASA (Henryson et al., 2004) and German Neumeyer (Schmidt et al., 1994) stations for comparison. Note that the value shown for SANAE IV during January is $20 \%$ lower than the clear-sky average (an absolute maximum), however, according to SSE only two clear-sky days are expected in this month. Thus, although the suggested values are lower than the expected averages they must be significantly within $20 \%$ of the actual values. Seasonal variations of up to $17 \%$ are expected from long-term averages (SSE, 2005), and thus the uncertainty is acceptable and a feasibility study erring towards the conservative follows.

Historical data of cloud cover was not appropriate for calculating precise levels of solar radiation at SANAE IV according to Norris (Norris, 1968), whose research concluded that, "...it is probably impossible to use cloud information to predict solar radiation".

Estimates of radiation levels on tilted surfaces were derived using the correlation of Perez et al. (Perez et al., 1988) that accounts for horizon brightening and circumsolar radiation are included in Table 1. The table also includes the calculated optimal tilt angles for collector surfaces throughout the year (of both global and beam radiation). A ground reflectivity of 0.7 was used

(Duffie et al., 1991), although Schmidt et al. (Schmidt et al., 1994) suggest a value of 0.84 for the German Neumeyer station.

\section{STATION ENERGY DEMAND ANALYSIS}

Annual diesel demand at SANAE IV amounts to approximately 347222 liters, of which 297872 liters is used by the diesel-electric generators for creating electricity and the remainder is used for re-fuelling the fleet of diesel-powered vehicles. Relatively small amounts of petrol and jetfuel are also required at the station to power Skidoos and aircraft respectively, a demand that 
totals approximately $5 \%$ of the overall fuel consumption at the station with diesel making up the difference. Annual averages of station electrical energy consumption have been calculated at $2910 \mathrm{kWh}$ per day (a value found to have a fair amount of activity related and seasonal dependence) with estimated maximum and minimum values of $5160 \mathrm{kWh}$ and $1440 \mathrm{kWh}$ respectively.

The station's summer base-load energy consumption (i.e. minimum values) was established as $60 \mathrm{~kW}$, which is supplied by two ADE turbo-charged 442T and one turbo-charged inter-cooled 442Ti diesel-electric generators equipped with waste heat recovery systems. The generators operate with an average electrical efficiency of $36.4 \%$, thus $3.6 \mathrm{kWh}$ of electrical energy is generated from every liter of diesel combusted (since the lower heating value of SAB diesel is $9.8 \mathrm{kWh} / \mathrm{L}$ ). The electrical mini-grid is a three-phase, $380 \mathrm{VAC}$ and $50 \mathrm{~Hz}$ system. Electrical and thermal power distribution of SANAE IV is shown in Figure 4, and an illustration of the average annual diesel consumption in Figure 5.

From an investigation of each of the energy consuming components shown in Figure 4 it was determined that solar energy supplemented either to the SANAE IV electrical mini-grid or to the snow smelter (a device that meets the station's fresh water requirements by melting snow) would offer the greatest benefit to the station (Olivier, 2005). The snow smelter must supply large amounts of fresh water for the summer takeover season, a six-week period during which the number of personnel resident at the station increases from approximately 10 to 80 people. The period is characterized by noticeable increased strain on the electrical generation system and as such load reductions present valuable opportunities for improving operation. 
Average fresh water consumption rates were determined from measured data and literature (Gleick, 2005) as 80 liters per person per day for all activities at the station. The snow smelter is filled three times per day with snow, and the fluid is heated to $30^{\circ} \mathrm{C}$ after each filling before the heating elements are switched off to stabilize the water at this temperature. Normally, however, due to the increased need for fresh water during the takeover, the water will be pumped at a temperature of about $10^{\circ} \mathrm{C}$.

Thus the snow smelter represents an energy intensive process requiring a minimum of 819 $\mathrm{kWh}$ /day during the takeover season, or more than $25 \%$ of average daily takeover electricity consumption of $3096 \mathrm{kWh} /$ day. This vitally important component of the station's operation presents a good match between the availability of solar energy and a need for greater energy supply. Conversely, it was found that the availability of solar energy and the need for space heating in the station, for instance, did not correlate well. In fact, the station required cooling during the summer months (Cencelli, 2002), while solar radiation levels during the winter were too low to justify supplementing the load with solar energy.

\section{DEVICE CHARACTERISTICS AND ENERGY PRODUCTION}

Characteristics of photovoltaic and solar thermal collectors were investigated in order to establish which devices are best suited for the utilization of solar energy in Antarctica. In order to assess efficiencies of photovoltaic systems the methodology presented by RETScreen (RETScreen, 2005) was implemented, resulting in an estimated overall system efficiency of 13 $\%$ (from panel to power-grid, including array and power conditioning losses). Captured solar power is to be transferred from a suggested $40 \mathrm{kWp}$ photovoltaic array to SANAE IV's mini-grid through a three-phase grid-tie inverter. Notice was also taken of research completed at the Australian Antarctic stations which established that, “...despite the greater collection potential 
offered by tracking systems, an annually optimized fixed system is the best overall design option when operational costs are assessed on a per area basis" (Williams et al., 2000).

The solar thermal collector was chosen based on a number of decisive factors. Low process temperatures, low ambient temperatures (resulting in large amounts of heat loss from collectors), the significant proportion of diffuse radiation compared to global radiation at SANAE IV (refer to Figure 2), availability of products, and difficulty in installing or maintaining tracking systems support the choice of flat-plate collectors over concentrating devices. It is also a flat-plate solar collector system (currently the only solar thermal system operational in Antarctica) that is functional at the Australian Davis station, “...supplying $100 \%$ of the hot water used for personal ablutions and laundry” (AAD, 2005).

The potential yield of a flat-plate solar collector was investigated by running simulations of the Solahart Bt collector (Solahart, 2005) to estimate potential yields. Figure 6 represents a schematic of the array connection to the snow smelter (a split system) also illustrating the controller and pumps that facilitate the heat transfer from the energy store to the snow smelter by coordinating pumping intervals. The collector is designed with drain-back capabilities, implying that at times of low solar radiation no fluid is present in the collector preventing heat transfer from the snow smelter to the environment. Assumptions include; using estimated average monthly radiation profiles, assuming a fixed average daily production of fresh water and not accounting for the variation in demand and available solar energy, using fixed average monthly ambient temperatures, and estimating the overall heat transfer coefficients for the heat exchanger and for losses from the snow smelter as $1500 \mathrm{~W} / \mathrm{K} \cdot \mathrm{m}^{2}$ and $20 \mathrm{~W} / \mathrm{K} \cdot \mathrm{m}^{2}$ respectively. The result is an estimated net annual collector efficiency of $29.3 \%$ (viz. an annual production of $60000 \mathrm{kWh}$ from a possible $204604 \mathrm{kWh}$ for a tilted array of $143 \mathrm{~m}^{2}$ ). 


\section{ECONOMIC ANALYSIS}

The basic methodology of the ensuing economic evaluation is detailed in a report created for the South African Department of Environmental Affairs and Tourism (DEAT) entitled "Cost Benefit Analysis" (DEAT, 2005). The analysis assesses Net Present Value (NPV), Internal Rates of Return (IRR), Net Annual Worth (NAW), Benefit Cost Ratio (B/C Ratio), payback periods and cost per kWh of energy produced in real monetary terms (i.e. relative to the Rand value in December 2005). A standard Minimum Attractive Rate of Return (MARR, also referred to as a "hurdle rate") of $8 \%$ was used in the analysis.

The NPV is calculated from Equation 1 by summing the initial capital expenditure $(C)$, annual maintenance $(M)$, annual labor $(L)$, annual fuel $(F)$ and annual external $(E)$ costs over the 25year lifetime of the project. External savings (or savings generated by reducing the programme's impact on the environment) have been taken from values suggested by Teetz (Teetz, 2003) as 5.61 R/L. The final purchase price of diesel included transport expenses to the station, and pointof-use costs were established as three times more expensive than the original purchase price of 5.36 R/L (Teetz, 2003; Guichard, 1996; Steel, 1993; Guichard, 1994). Fuel savings of the photovoltaic and flat-plate solar thermal systems amounted to 9958 liters and 12244 liters respectively. Purchase prices of $35 \mathrm{R} / \mathrm{Wp}$ were used for the photovoltaic panels, while Solahart Bt flat-plate collectors can be purchased from R 7000 per panel (of $1.98 \mathrm{~m}^{2}$ ).

$$
N P V=\sum_{n=0}^{N}\left(C_{n}+M_{n}+L_{n}+F_{n}+E_{n}\right) \cdot\left(\frac{1}{(1+i)^{n}}\right)
$$

Figures 7 and 8 illustrate the results of installing the recommended photovoltaic or solar thermal systems respectively (i.e. a hybrid solar-diesel system) at a MARR of $8 \%$ and fuel price 
escalation rate of $5 \%$. The IRR shown in Table 2 is calculated by solving Equation 3, where the PWF (Present Worth Factor) is defined by Equation 2. The PWF is a function of an interest rate $(i)$, and time-period in years $(n)$.

$P W F(i, n)=\frac{1}{(1+i)^{n}}$

$\sum_{k=0}^{N}(P W F(I R R, k)) \cdot$ Income $_{k}=\sum_{k=0}^{N}(P W F(I R R, k)) \cdot$ Expenses $_{k}$

$\mathrm{B} / \mathrm{C}$ Ratios given in Table 2 are established by calculating the value of $\mathrm{B} / \mathrm{C}$ ratios from Equation 4.

$$
B C=\frac{\sum_{k=0}^{N}(P W F(M A R R, k)) \cdot \text { Income }_{k}}{\sum_{k=0}^{N}(P W F(M A R R, k)) \cdot \text { Expenses }_{k}}
$$

Final energy generation costs for the Diesel-Photovoltaic and Diesel-Solar Thermal hybrid systems were calculated as $3.20 \mathrm{R} / \mathrm{kWh}$ and $3.13 \mathrm{R} / \mathrm{kWh}$ respectively. They are calculated by solving Equation 5.

Cost $=\frac{\sum_{k=0}^{N}(P W F(\text { MARR }, k)) \cdot \text { Expenses }_{k}}{\sum_{k=0}^{N}{\text { AnnualEnergy Pr } \text { oduction }_{k}}}$

The feasibility of the suggested solar system hinges largely on the economic benefits achievable by commissioning the recommended devices. In the light of difficult to establish criteria such as changing fuel purchase prices, the cost of transporting fuel to Antarctica, installation costs, 
annual maintenance costs and external savings, the results of this analysis are subject to change.

Care has been taken, however, to establish how sensitive the suggested system is to this change (as is evident in Table 2), and to use conservative estimates where applicable.

\section{CONCLUSION}

The presented analysis procedure was found to be applicable for assessing the solar energy potential at SANAE IV in Antarctica. Although the decrease in fuel consumption from the suggested solar systems is relatively small (viz. 3-4 \% of average annual diesel consumption), financial savings generated and electrical load reduction in the demanding summer takeover months justify effort expended. This is especially true if external costs are considered. The short payback period of the suggested flat-plate solar thermal system of 6 years is also very attractive. The results clearly show that the proposed hybrid systems are technically feasible, as well as economically viable for utilizing solar energy at SANAE IV.

\section{Acknowledgements}

The authors would like to thank the South African Department of Environmental Affairs and Tourism, Subdirectorate Antarctica and Islands for funding and logistical support, as well as the South African Department of Science and Technology who through the South African National Research Foundation also contributed in funding.

\section{Appendices}

A1: SAMPLE CALCULATIONS OF ECONOMIC ANALYSIS FOR THE PHOTVOLTAIC SYSTEM 
A mathematical analysis subordinate to discussion of the economic evaluation above (in the section entitled Economic Analysis) has been included below. Table A1 provides a list of all annual costs, after which the relevant sample calculations are given.

Table A1: List of annual system costs pertaining to Equation 1

\begin{tabular}{|l|l|l|l|}
\hline Cost Item & $\begin{array}{l}\text { Diesel-only system } \\
\text { (Rand) }\end{array}$ & $\begin{array}{l}\text { Diesel-photovoltaic } \\
\text { system (Rand) }\end{array}$ & $\begin{array}{l}\text { Diesel-Solar Thermal } \\
\text { system (Rand) }\end{array}$ \\
\hline Initial Capital Expenditure (C) & 0.00 & -1653167.13 & -881200.00 \\
\hline Annual Maintenance Cost (M) & -30000.00 & -103802.10 & -63700.00 \\
\hline Annual Labor Cost (L) & -20000.00 & -21000.00 & -25000.00 \\
\hline Annual Fuel Cost (F) & -5038455.74 & -4870319.96 & -4831712.89 \\
\hline Annual External Cost (E) & 0.00 & 53554.11 & 65851.12 \\
\hline
\end{tabular}

\section{Net Present Value}

The NPV of cash flows has been calculated with the help of Equations 1 and 2. For example, the NPV of cash flows for the diesel-only system (excluding externalities) after the first year equals the total costs at the end of year 1 brought back by the PWF with an interest rate equal to the hurdle rate.

$$
\begin{aligned}
& N P V=\sum_{n=0}^{N}\left(C_{n}+M_{n}+L_{n}+F_{n}\right) \cdot\left(\frac{1}{(1+i)^{n}}\right) \\
& N P V=-5079770.85 \cdot\left(\frac{1}{(1+0.08)^{1}}\right)
\end{aligned}
$$

\section{Internal Rate of Return}

The IRR can easily be calculated with the help of Microsoft Excel's formulae function, however, by way of example the formula and sample calculation is given here. The IRR is that interest rate 
which solves Equation A3. For example, the IRR in Table A2 at the end of year six is calculated from the column "Yearly Cashflows" in the same table as:

$\sum_{k=0}^{N}(P W F(I R R, k)) \cdot$ Income $_{k}=\sum_{k=0}^{N}(P W F(I R R, k)) \cdot$ Expenses $_{k}$

Which is solved by:

$$
\begin{array}{r}
1653167.13\left[\frac{1}{(1+0.1983)^{0}}\right]=92585.66\left[\frac{1}{(1+0.1983)^{1}}\right]+100236.95\left[\frac{1}{(1+0.1983)^{2}}\right]+108301.02\left[\frac{1}{(1+0.1983)^{3}}\right]+\ldots \\
\ldots 116798.22\left[\frac{1}{(1+0.1983)^{4}}\right]+125752.34\left[\frac{1}{(1+0.1983)^{5}}\right]+135184.67\left[\frac{1}{(1+0.1983)^{6}}\right]
\end{array}
$$

\section{Benefit Cost Ratio}

The B/C Ratio is easily calculated as the sum of the total benefits projected to the same point in time (in this instance the NPV) divided by the sum of the total costs. Therefore (excluding externalities):

$$
B C=\frac{\sum_{k=0}^{N}(P W F(M A R R, k)) \cdot \text { Income }_{k}}{\sum_{k=0}^{N}(P W F(M A R R, k)) \cdot \text { Expenses }_{k}}
$$

Which can be calculated from the first four columns in Table A1 (viz. Capital, Fuel, Maintenance and Labour), where "Fuel" is the only column that represents an income as given in Equation A5. Thus, the B/C-Ratio at the end of year 1 is calculated as: 


$$
B C=\frac{\left[\frac{1}{(1+0.08)^{1}}\right] \cdot 168135.79}{\left[\frac{1}{(1+0.08)^{0}}\right] \cdot 1653167.13+\left[\frac{1}{(1+0.08)^{1}}\right] \cdot 74540.13+\left[\frac{1}{(1+0.08)^{1}}\right] \cdot 1010}
$$

\section{Cost of Energy Produced}

The cost of energy generation has been calculated by; summing the respective total costs of the system in question (i.e. diesel-only or hybrid) over the 25 -year project lifetime, and then dividing by the power generated after that amount of time.

Cost $=\frac{\sum_{k=0}^{N}(P W F(M A R R, k)) \cdot \text { Expenses }_{k}}{\sum_{k=0}^{N}{\text { AnnualEnergy } \operatorname{Pr} \text { oduction }_{k}}}$

Thus, the normal generation costs of the diesel-only system are calculated as (cost values can be seen at the bottom of Table A1):

Cost $=\frac{0+84903277.43+351801.17+234534.11}{24 \cdot 1061971}$ 
Table A1: Sample results for the solar PV system (column A is for diesel-only and column B is for the hybrid system)

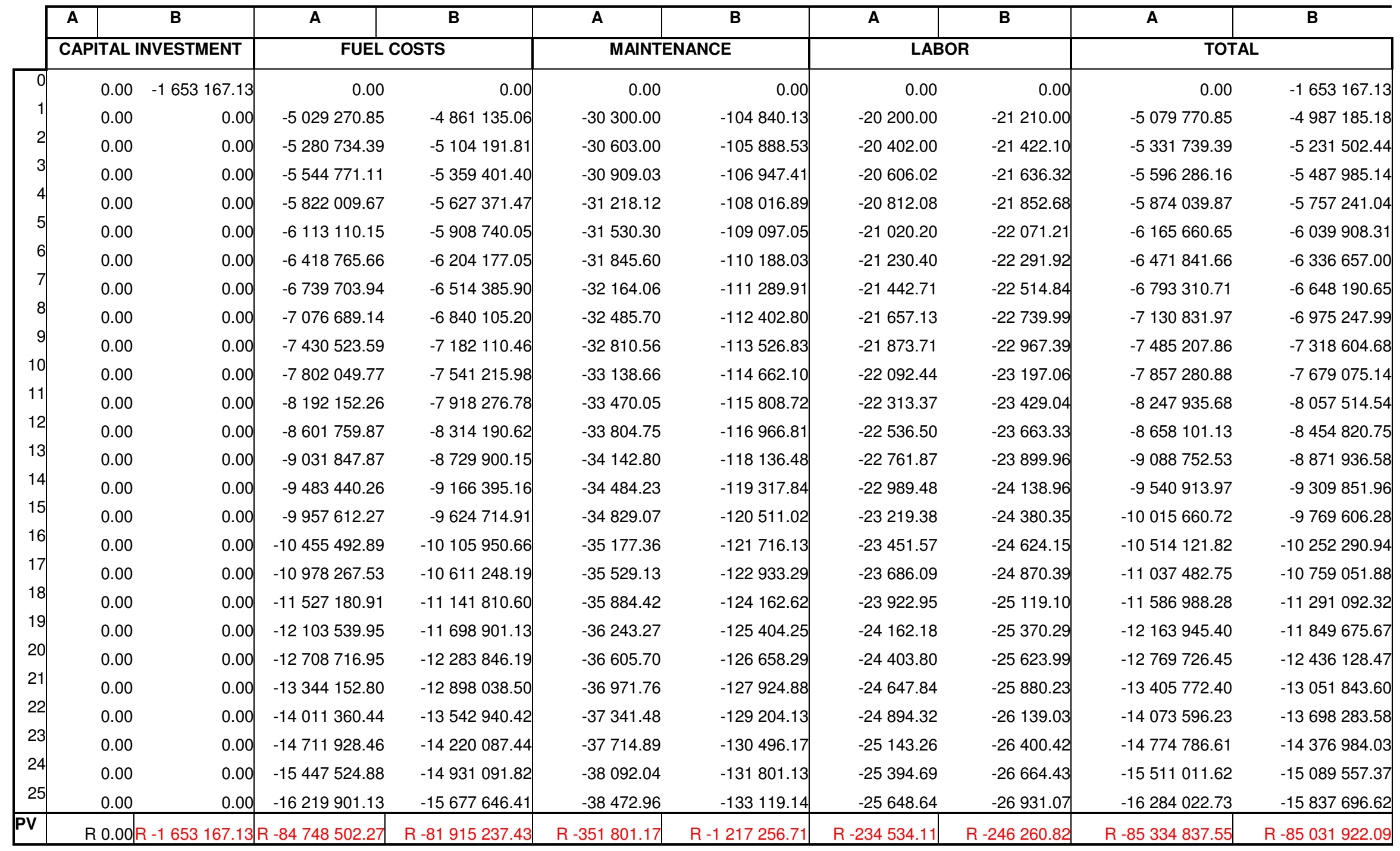




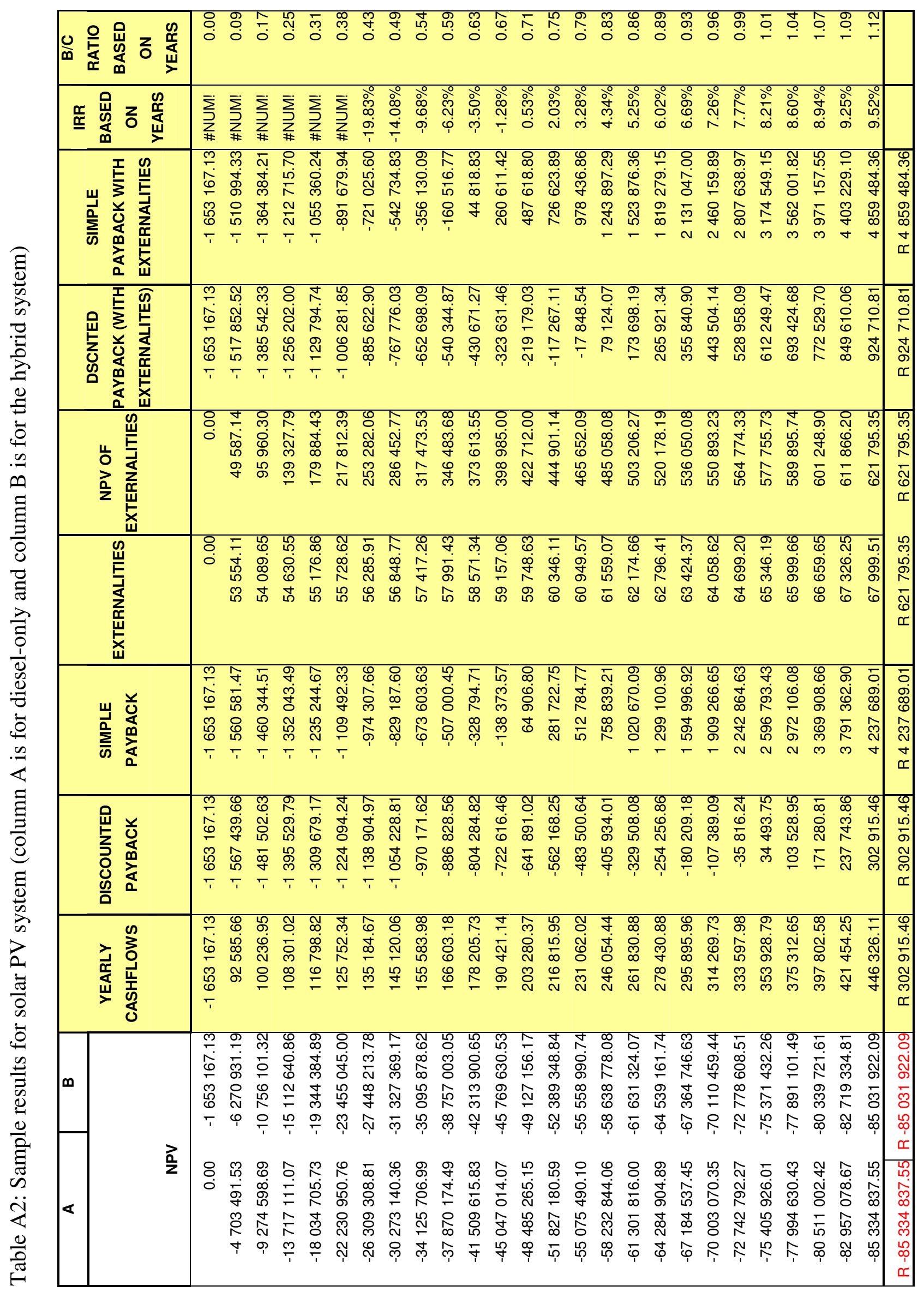




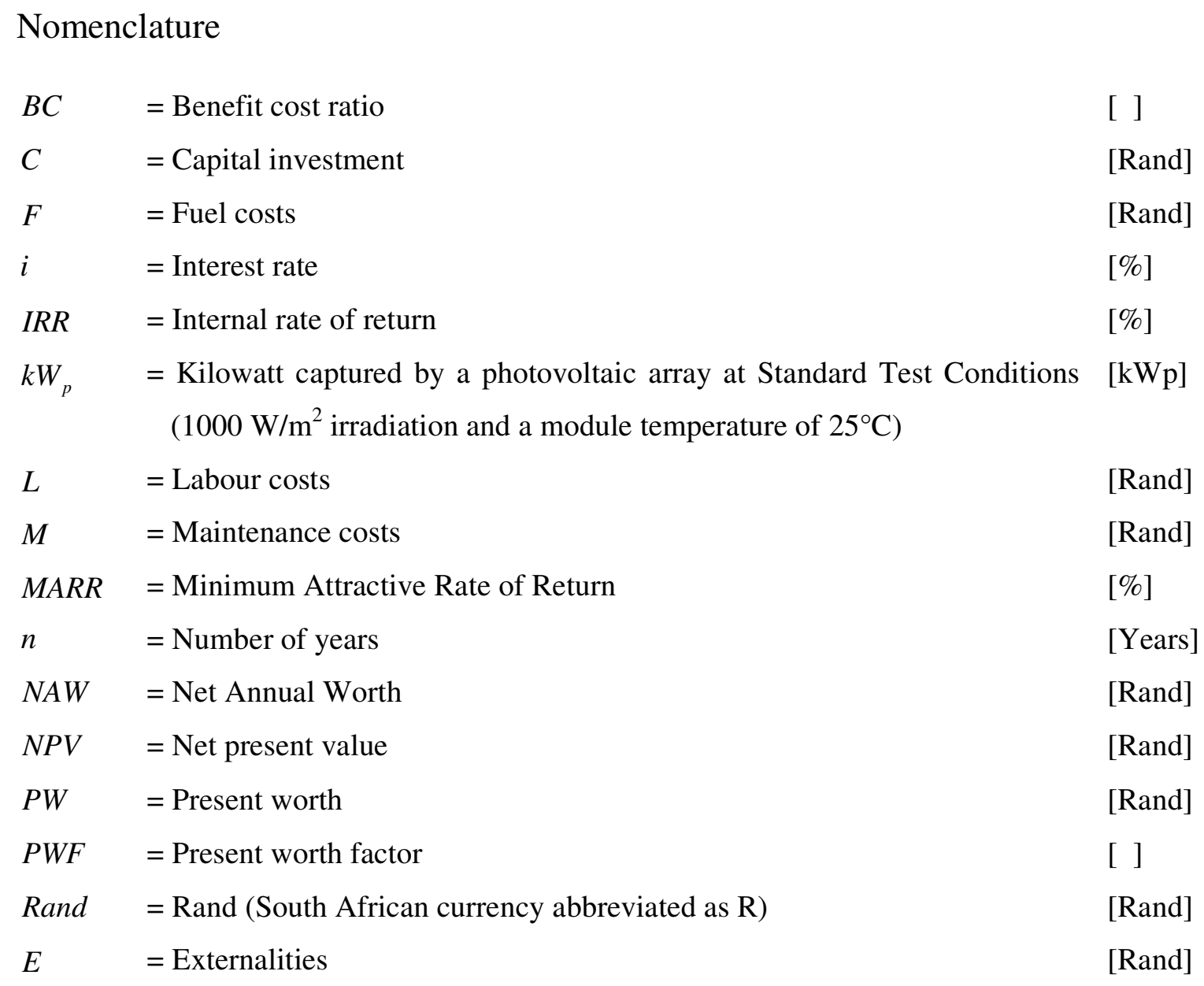

\section{References}

AAD., 2005. Australian Antarctic Division, homepage of the Australian Antarctic Division www.aad.gov.au

Cencelli, N., 2002. Energy Audit and Study of the Heating and Ventilation System of the SANAE IV Base, B.Eng Thesis, Department of Mechanical Engineering, University of Stellenbosch

COMNAP., 2005. Council of Managers of National Antarctic Programmes, homepage of the Council of Managers of National Antarctic Programmes http://www.comnap.aq/comnap/comnap.nsf/P/Pages/Operations.ENMANET/ DEAT., 2005. Cost Benefit Analysis, Section 8 of the Integrated Environmental Management Information Series produced for the Department of Environmental Affairs and Tourism 
(DEAT), available at

http://www.environment.gov.za/Documents/Publications/2005Jan7/Book3.pdf

Duffie, J.A., Beckman, W.A., 1991. Solar Engineering of Thermal Processes, second ed. Wiley Interscience, New York

Erbs, D.G., Klein, S.A., Duffie, J.A., 1982. Estimation of the Diffuse Radiation Fraction for Hourly, Daily and Monthly Average Global Radiation, Solar Energy, Vol. 28, No. 4, pp. 293302.

Gleick, P., 2005. Hyperforum on Long Term Sustainability, produced from the World Resource Institute, available at http://www.hf.caltech.edu/hf/b3/library/kio-wat/w_table4.html

Guichard, A., 1994. Towards New Energy Systems for Antarctica, proceedings of the Sixth Symposium on Antarctic Logistics and Operations, Rome, Italy, August 1994, pp. 81-95

Guichard, A., Brown, C., Lyons, D., 1996. Analysis of the Potential for Wind and Solar energy Systems in Antarctica, Institute of Antarctic and Southern Ocean Studies, University of Tasmania, Hobart, Australia.

Henryson, M., Svensson, M., 2004. Renewable Power for the Swedish Antarctic Station WASA, Master of Science Thesis, Department of Energy and Technology, Stokholm, Sweden Hottel, H.C., 1976. A Simplified Model for Estimating the Transmittance of Direct Solar Radiation through Clear Atmospheres, Solar Energy, vol. 18, pg. 129-134

Neumeyer, 2005. German Neumeyer Antarctic Station, homepage of the German Neumeyer Antarctic Station http://www.awi-bremerhaven.de/

Norris, D.J., 1968. Correlation of Solar Radiation with Clouds, Pergamon Press, Great Britain, Solar Energy, vol.12, pp. 107-112

Olivier, J.R., 2005. Technical and Economic Evaluation of the Utilization of Solar Energy at South Africa's SANAE IV Base in Antarctica, MSc Thesis, Department of Mechanical Engineering, University of Stellenbosch 
Perez, R., Stewart, R., Seals, R., Guertin, T., 1988. The Development and Verification of the Perez Diffuse Radiation Model, Sandia National Laboratories Contractor Report SAND887030

RETScreen, 2005. Renewable Energy Technology (RET) Screen International Clean Energy Decision Support Center, homepage of RETScreen International http://www.retscreen.net SAWS., 2005. South African Weather Service, homepage of the South African Weather Service $\underline{\text { http://www.weathersa.co.za/ }}$

Schmidt, T., Langlo, G.K., 1994. Radiation Measurements at the German Antarctic Station Neumeyer 1982-1992, Reports on Polar Research, vol. 146, ISSN 0176-5027

Solahart, 2005. Solahart South Africa, Bryanston, P O Box 69560, e-mail jim@ solahart.co.za, homepage of Solahart http://www.solahart.com

SSE., 2005. Langley Research Center of NASA Surface Meteorology and Solar Energy Dataset, homepage of the Langley Research Center SSE Dataset http://eosweb.larc.nasa.gov/sse/

Steel, J.D., 1993. Alternative Energy Options for Antarctic Stations, Graduate Diploma Thesis, Institute of Antarctic and Southern Ocean Studies (IASOS), University of Tasmania

Teetz, H., 2003. Assessment of the wind power potential at SANAE IV base, Antarctica: a technical and economic feasibility study, Renewable Energy, 28 (2003), 2037-2061

Williams, G., Magill, P., Guichard, A., Paterson, C., 2000. Making the Most of Solar Energy in Antarctica, Poster Presentation to the Ninth Symposium on Antarctic Logistics and Operations, Tokyo, July 2000 


\section{Tables}

Table 1: Expected average values of insolation at SANAE IV

\begin{tabular}{lccccccc}
\hline Month & $\begin{array}{l}\text { Global } \\
\text { Horisontal } \\
\text { Insolation } \\
\left(\mathrm{kWh} / \mathrm{m}^{2} \text {.day }\right)\end{array}$ & $\begin{array}{l}\text { Horisontal } \\
\text { Beam } \\
\text { Insolation } \\
\left(\mathrm{kWh} / \mathrm{m}^{2} \text {.day }\right)\end{array}$ & $\begin{array}{l}\text { Optimum } \\
\text { global Tilt } \\
\left.{ }^{\circ}\right)\end{array}$ & $\begin{array}{l}\text { Optimum } \\
\text { beam Tilt } \\
\left.{ }^{\circ}\right)\end{array}$ & $\begin{array}{l}\text { Global Tilted } \\
\text { Insolation } \\
\left(\mathrm{kWh} / \mathrm{m}^{2} . \text { day }\right)\end{array}$ & $\begin{array}{l}\text { Titled Beam } \\
\text { Insolation } \\
\left(\mathrm{kWh} / \mathrm{m}^{2} \text {.day }\right)\end{array}$ & $\begin{array}{l}\text { Avg } \\
\text { Temp } \\
\left({ }^{\circ} \mathrm{C}\right)\end{array}$ \\
\hline Jan & 7.26 & 2.92 & 52 & 39 & 8.05 & 3.54 & -6.6 \\
$\mathrm{Feb}$ & 4.78 & 1.88 & 63 & 53 & 6.11 & 2.99 & -10.3 \\
Mar & 2.13 & 0.74 & 74 & 68 & 3.51 & 1.99 & -14.9 \\
Apr & 0.72 & 0.26 & 84 & 83 & 2.54 & 2.12 & -18.2 \\
May & 0.01 & 0.01 & 90 & 90 & 0.01 & 0.00 & -19.5 \\
Jun & 0.00 & 0.00 & 00 & 00 & 0.00 & 0.00 & -20.1 \\
Jul & 0.00 & 0.00 & 00 & 00 & 0.00 & 0.00 & -23.1 \\
Aug & 0.17 & 0.06 & 88 & 87 & 1.24 & 1.13 & -22.9 \\
Sep & 1.53 & 0.59 & 78 & 75 & 3.23 & 2.21 & -22.9 \\
Oct & 3.93 & 1.49 & 69 & 68 & 6.86 & 3.78 & -18.2 \\
Nov & 6.23 & 2.47 & 52 & 44 & 7.14 & 3.18 & -12.8 \\
Dec & 7.63 & 3.09 & 48 & 35 & 8.30 & 3.55 & -7.1 \\
Avg & 2.87 & 1.13 & 70 & 64 & 3.92 & 2.04 & -16.4 \\
\hline
\end{tabular}


Table 2: Financial outcomes under various economic conditions

\begin{tabular}{|c|c|c|c|c|c|c|}
\hline \multirow{3}{*}{\begin{tabular}{|l} 
MARR \\
Fuel Price Escalation \\
\end{tabular}} & \multicolumn{3}{|c|}{ Solar Photovoltaic } & \multicolumn{3}{|c|}{ Solar Thermal } \\
\hline & \multicolumn{6}{|c|}{$8 \%$} \\
\hline & $7 \%$ & $5 \%$ & $3 \%$ & $7 \%$ & $5 \%$ & $3 \%$ \\
\hline Breakeven period (years) & 16 & 21 & $\mathrm{n} / \mathrm{a}$ & 6 & 6 & 7 \\
\hline $\operatorname{IRR}(\%)$ & 12 & 10 & 7 & 27 & 24 & 22 \\
\hline NAW (Rand after 25 years) & 91037 & 26907 & -21335 & 269729 & 190873 & 131554 \\
\hline NPV (Rand after 25 years) & 1024882 & 302915 & -240183 & 3036554 & 2148811 & 1481007 \\
\hline $\mathrm{B} / \mathrm{C}$ (after 25 years) & 1.40 & 1.10 & 0.90 & 3.25 & 2.50 & 2.00 \\
\hline MARR & \multicolumn{6}{|c|}{$4 \%$} \\
\hline Fuel Price Escalation & $7 \%$ & $5 \%$ & $3 \%$ & $7 \%$ & $5 \%$ & $3 \%$ \\
\hline Breakeven period (years) & 13 & 15 & 18 & 5 & 5 & 6 \\
\hline $\operatorname{IRR}(\%)$ & 12 & 10 & 7 & 27 & 25 & 22 \\
\hline NAW (Rand after 25 years) & 170969 & 91622 & 33498 & 330651 & 233083 & 161614 \\
\hline NPV (Rand after 25 years) & 2956406 & 1584322 & 579252 & 5717633 & 4030493 & 2794640 \\
\hline $\mathrm{B} / \mathrm{C}$ (after 25 years) & 2.00 & 1.50 & 1.20 & 4.75 & 3.50 & 2.75 \\
\hline
\end{tabular}




\section{Figure Captions}

Figure 1: Five-year average January daily radiation at Neumeyer station (1994 to 1998) compared to SSE data

Figure 2: Comparison of SANAE IV measured data with the SSE dataset

Figure 3: Monthly-average global horisontal radiation at four Antarctic stations

Figure 4: Peak power demand breakdown of all energy consumers at SANAE IV (updated from Teetz, 2002)

Figure 5: Seasonal variations of diesel consumption

Figure 6: Schematic of solar thermal collector connected to Snow Smelter

Figure 7: NPV of savings generated by photovoltaic system (MARR $8 \%$ and $0 \%$ )

Figure 8: NPV of savings generated by solar thermal system (MARR $8 \%$ and $0 \%$ ) 


\section{Figures}

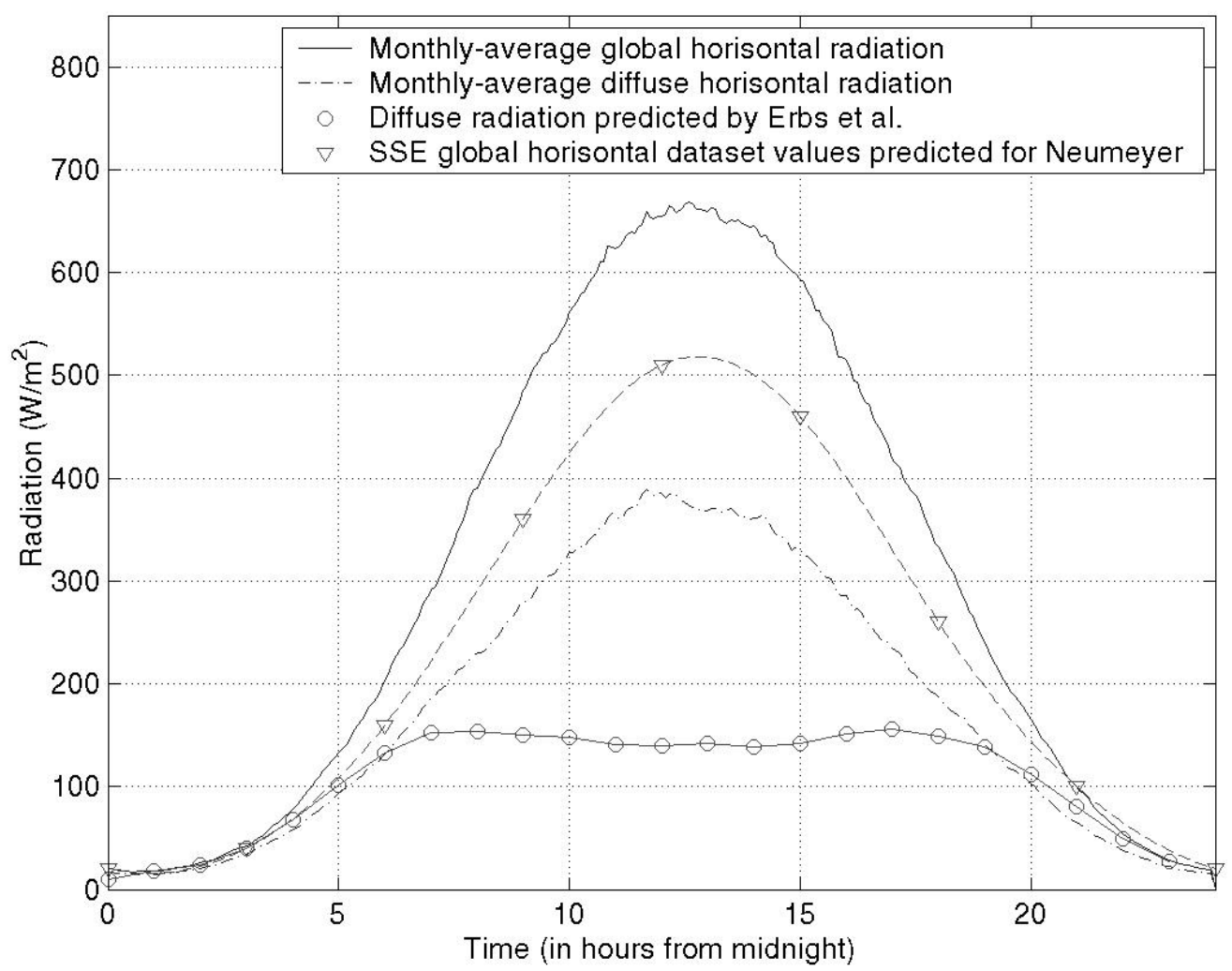

Figure 1: Five-year average January daily radiation at Neumeyer station (1994 to 1998) compared to SSE data 


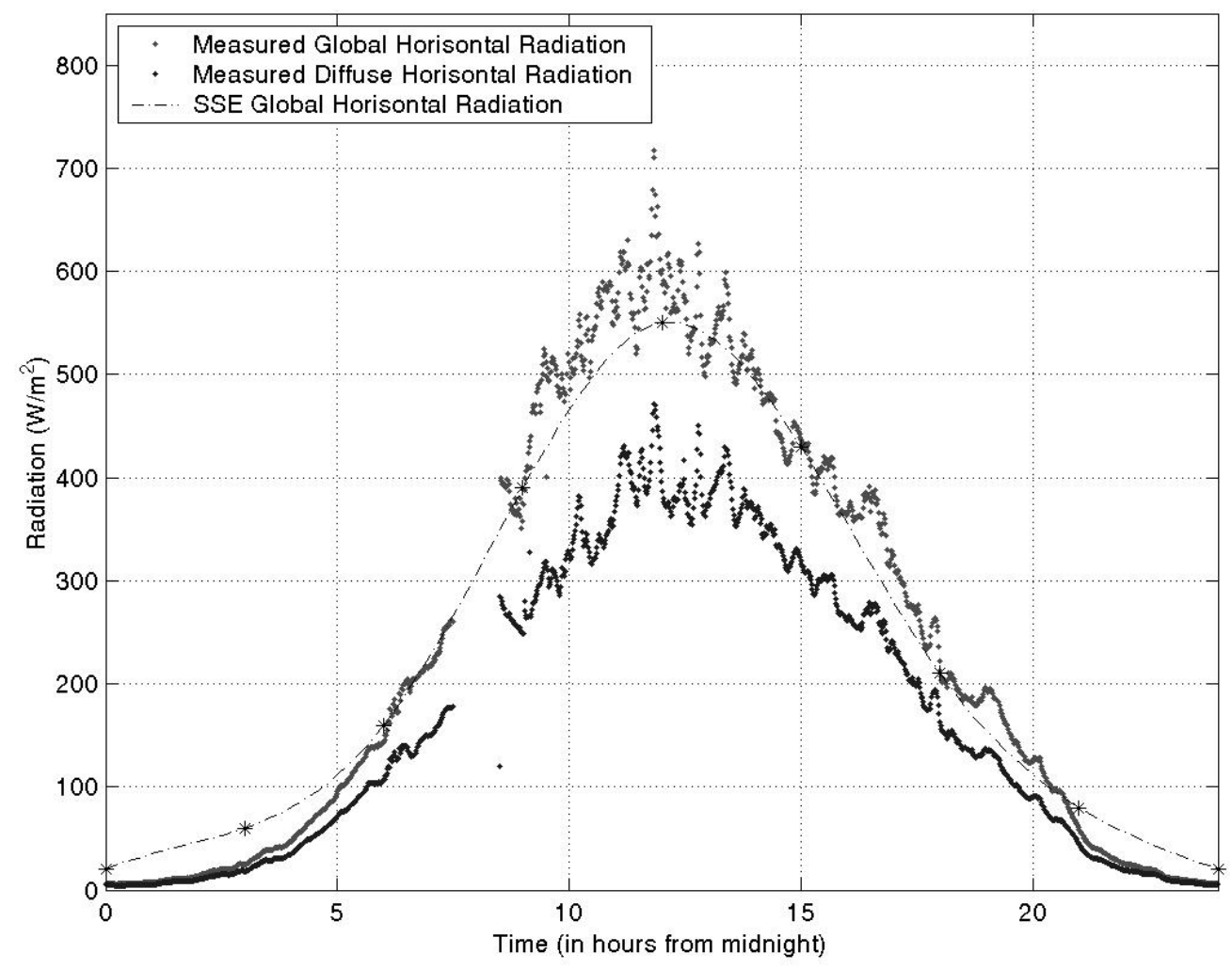

Figure 2: Comparison of SANAE IV measured data with the SSE dataset 


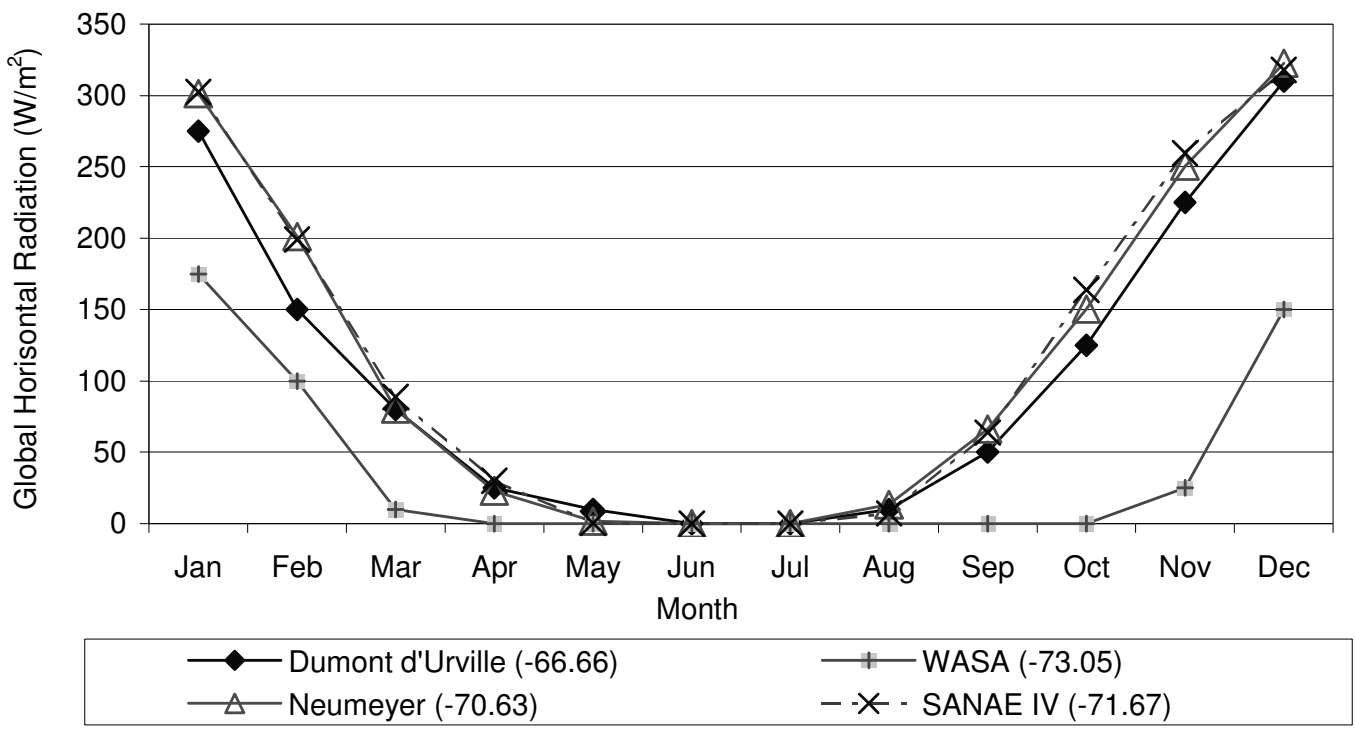

Figure 3: Monthly-average global horisontal radiation at four Antarctic stations 


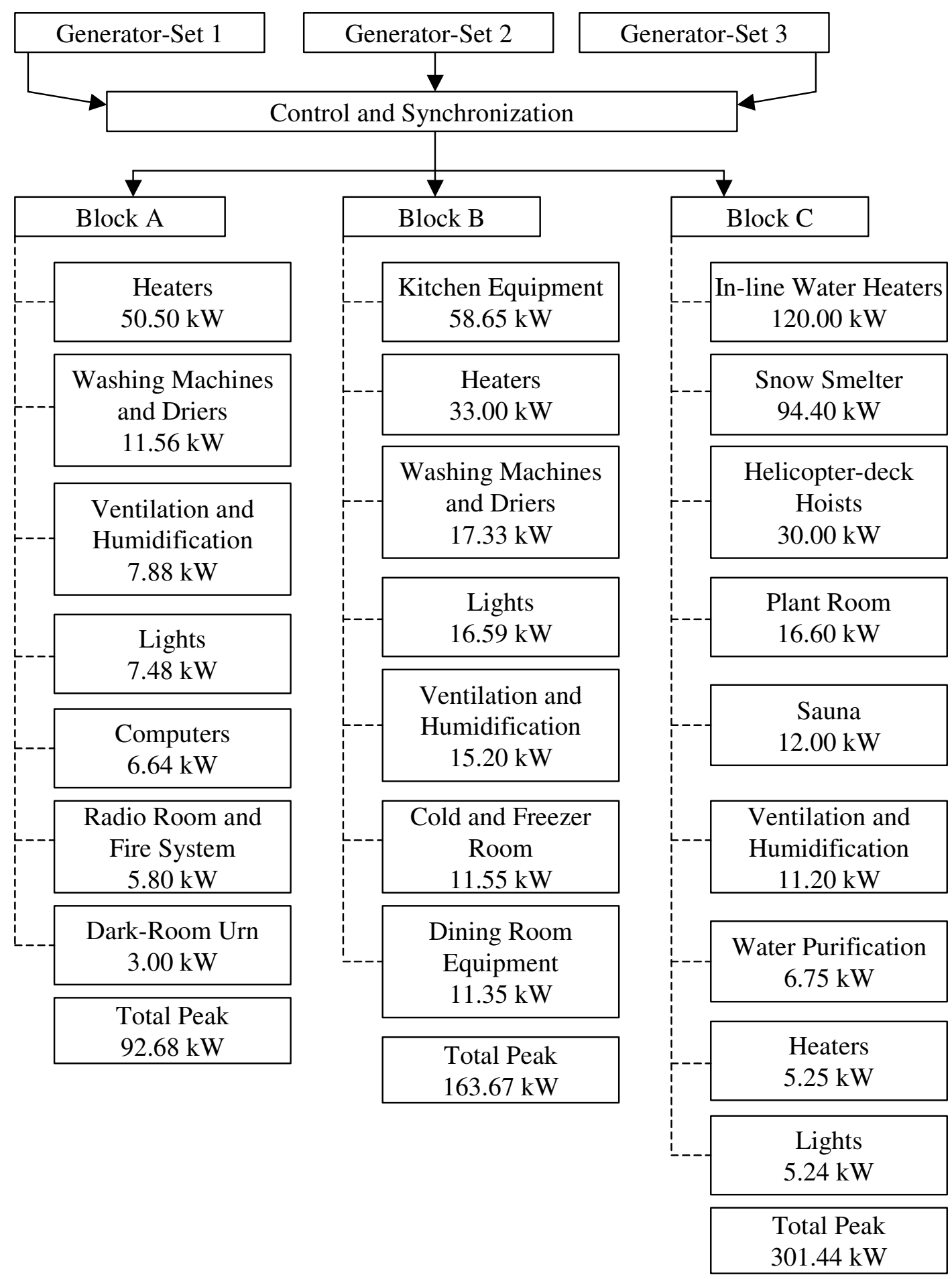

Figure 4: Peak power demand breakdown of all energy consumers at SANAE IV (updated from Teetz, 2002) 


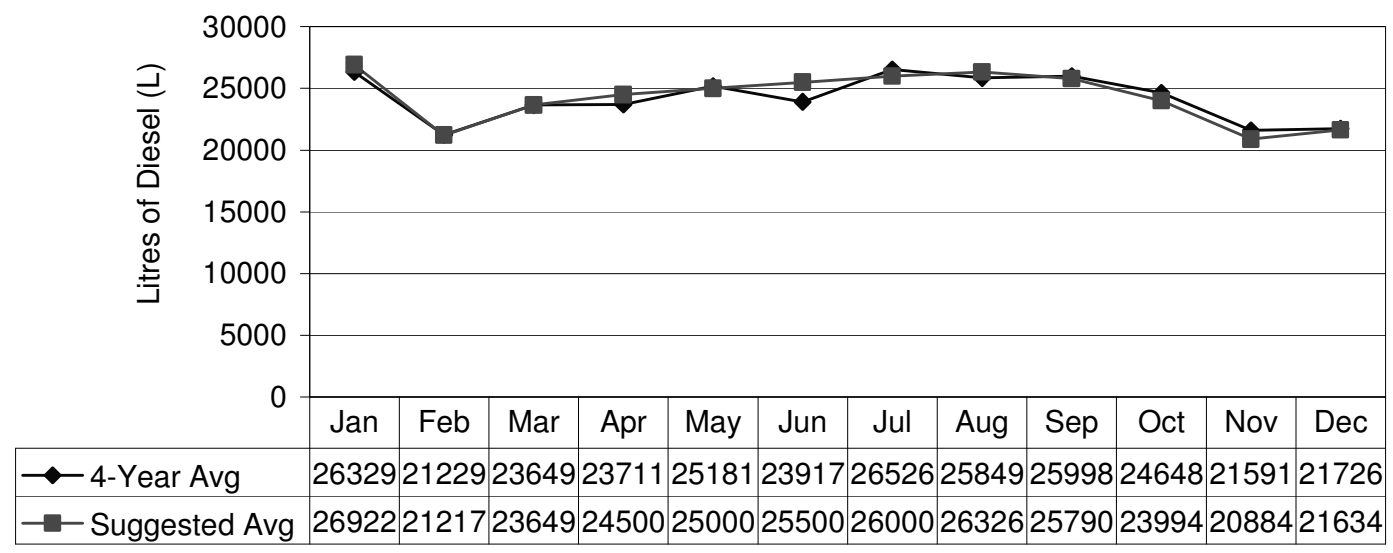

Figure 5: Seasonal variations of diesel consumption 


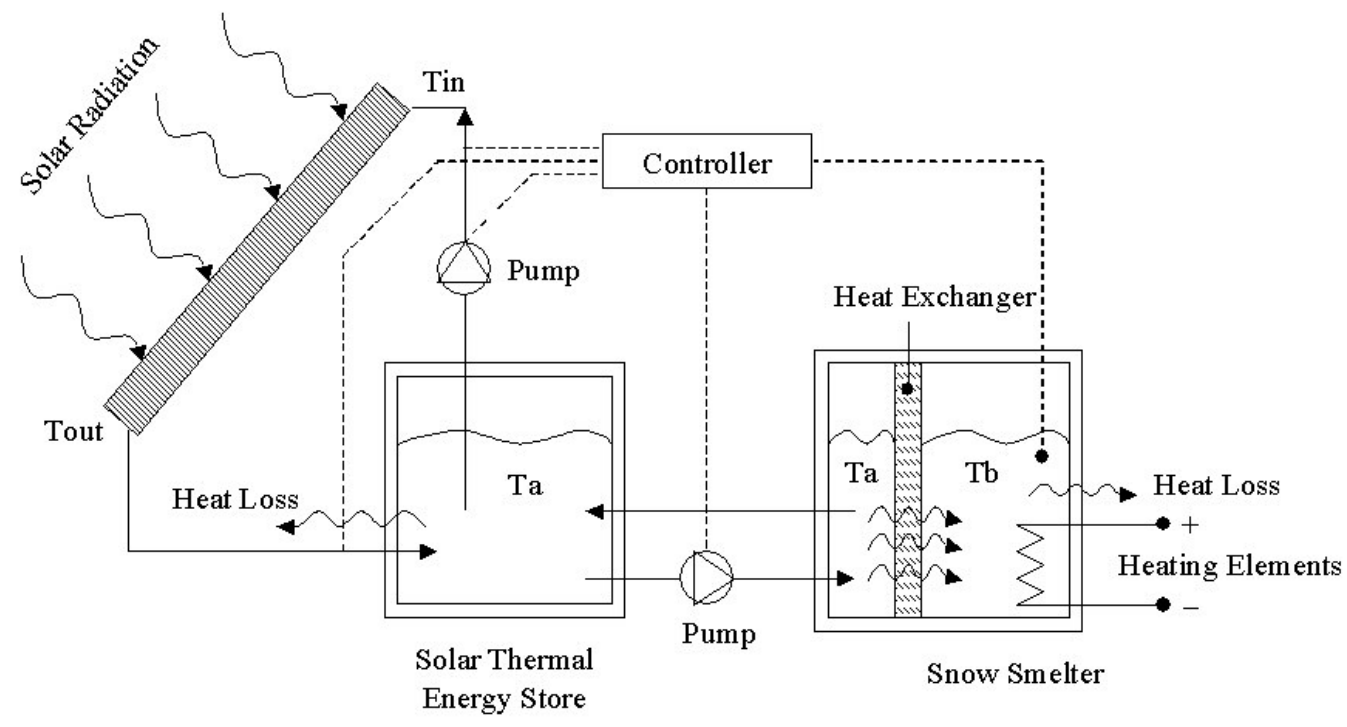

Figure 6: Schematic of solar thermal collector connected to Snow Smelter 


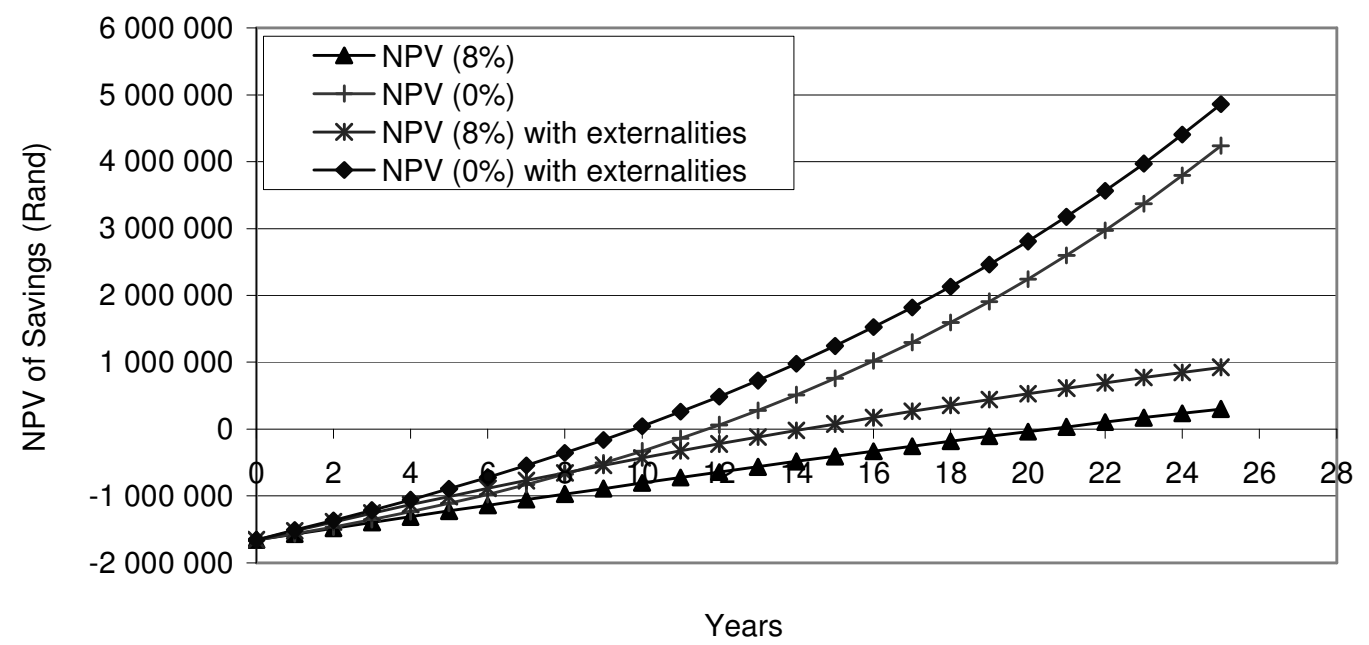

Figure 7: NPV of savings generated by photovoltaic system (MARR $8 \%$ and $0 \%$ ) 


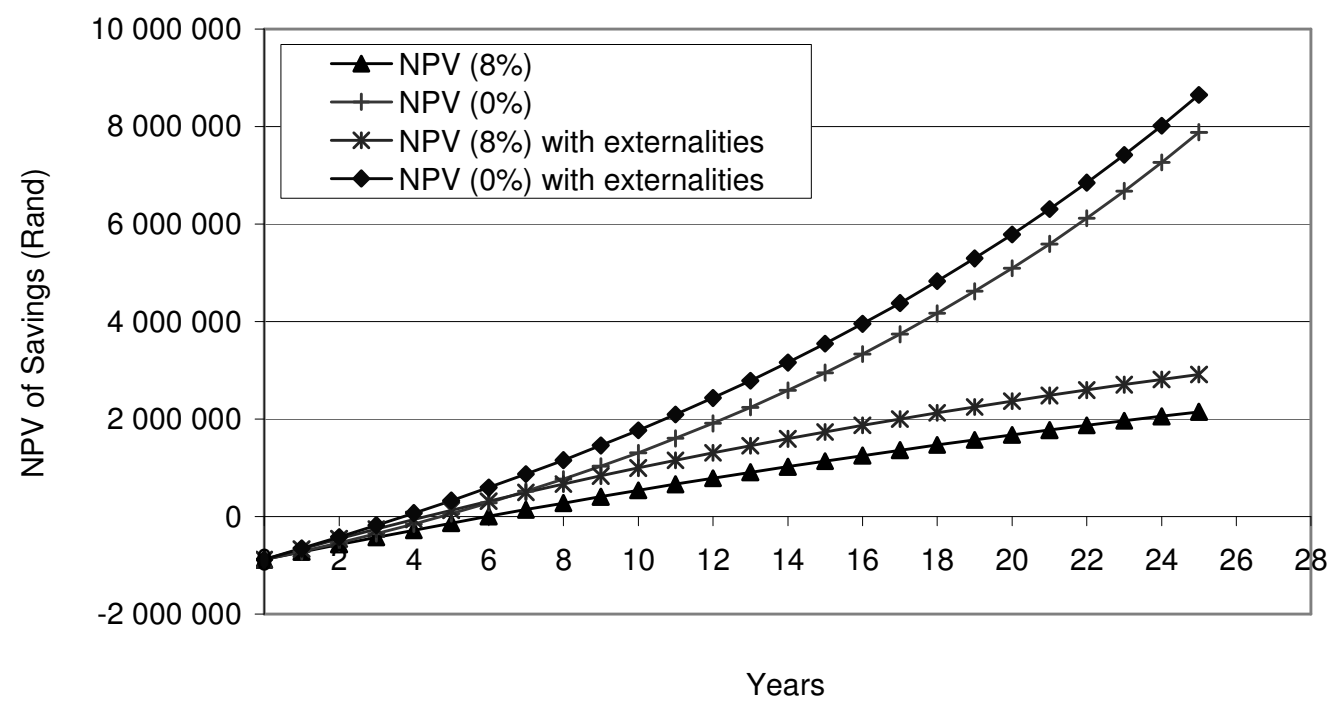

Figure 8: NPV of savings generated by solar thermal system (MARR $8 \%$ and $0 \%$ ) 